Research Article

\title{
Protein profile of rice (Oryza sativa) seeds
}

\author{
Yanhua Yang ${ }^{\#}$, Li Dai ${ }^{\#, ~ H e n g c h u a n ~ X i a, ~ K e m i n g ~ Z h u, ~ H a i j u n ~ L i u ~ a n d ~ K e p i n g ~ C h e n ~}$ \\ Institute of Life Sciences, Jiangsu University, Zhenjiang, PR China.
}

\begin{abstract}
Seeds are the most important plant storage organ and play a central role in the life cycle of plants. Since little is known about the protein composition of rice (Oryza sativa) seeds, in this work we used proteomic methods to obtain a reference map of rice seed proteins and identify important molecules. Overall, 480 reproducible protein spots were detected by two-dimensional electrophoresis on $\mathrm{pH}$ 4-7 gels and 302 proteins were identified by MALDI-TOF MS and database searches. Together, these proteins represented 252 gene products and were classified into 12 functional categories, most of which were involved in metabolic pathways. Database searches combined with hydropathy plots and gene ontology analysis showed that most rice seed proteins were hydrophilic and were related to binding, catalytic, cellular or metabolic processes. These results expand our knowledge of the rice proteome and improve our understanding of the cellular biology of rice seeds.
\end{abstract}

Keywords: mass spectrometry, proteomic analysis, rice seed, two-dimensional electrophoresis.

Received: July 6, 2012; Accepted: October 23, 2012.

\section{Introduction}

Rice (Oryza sativa L.) is the main food source for more than two-third of the world's population (Sasaki and Burr, 2000), especially in Southeast Asia (Nwugo and Huerta, 2011; Wang et al., 2011). With the completion of the rice genome sequencing program, rice has become the model organism in molecular biological research of monocotyledons (Agrawal and Rakwal, 2011; Li et al., 2011). The International Rice Genome Sequencing Project (IRGSP) has generated high-quality sequences that cover $95 \%$ of the $389 \mathrm{Mb}$ rice genome and has produced a genomic map for this species (Liu and Xue, 2006).

In recent years, many studies have investigated the functional genomics of rice. Traditional functional genomics have investigated mainly the changes in mRNA abundance in histiocytes. However, because of transcriptional regulation, mRNA levels do not provide a true indication of protein expression levels (Jugran et al., 2010; Ding et al., 2012). On the other hand, some proteins undergo complex post-translational modifications such that changes in the level of active protein may be more significant than those in the total protein content. Proteomic analysis was first described by Wilkins and Williams (1994) and seeks to study all proteins expressed in a cell, tissue or organism at a specific time or under specific circumstances by maximizing protein separation and identification (Wilkins et al., 1998).

Send correspondence to Keping Chen. Institute of Life Sciences, Jiangsu University, 301 Xuefu Road, Zhenjiang, Jiangsu Province 212013, PR China. E-mail: kpchen@ujs.edu.cn.

"These authors contributed equally to this work.
Two-dimensional electrophoresis (2-DE) combined with mass spectrometry (MS) are still the core tools for identifying differentially expressed proteins in proteomics (Yang et al., 2006, 2007a,b; Chitteti and Peng, 2007; Torabi et al., 2009; Chi et al., 2010; Ahrné et al., 2011; Fan et al., 2011; He et al., 2011; Nwugo and Huerta, 2011; Ding et al., 2012; Kalli and Hess, 2012).

Seeds are important plant storage organs that play a central role in the life cycle of plants because they are essential for plant reproduction and the initial stages of offspring formation (Yang et al., 2009). Seed biology is a major subject in plant research, although most studies have focused on seed dormancy and germination mechanisms (Koornneef et al., 2002; Finch-Savage and Leubner-Metzger, 2006; Yang et al., 2007b; Vaughan et al., 2008; He et al., 2011), with little being known about seed protein composition. Since proteomics is a well-established means of assessing global changes in protein profiles (Agrawal et al., 2006; Agrawal and Rakwal, 2011; Fan et al., 2011), in this study we used 2-DE and MALDI-TOF-MS to examine the proteomic profile of rice seeds. Our specific goals were (1) to determine the proteomic profile of rice seeds, (2) to identify the main protein components involved and (3) to understand the functional characteristics of the identified proteins.

\section{Materials and Methods}

\section{Seeds}

Seeds of the Nipponbare strain of rice (O. sativa $\mathrm{L}$. spp. japonica, cv. Nipponbare, AA genome) were used in this work. 


\section{Protein extraction}

The rice seeds were peeled and washed three times using purified water, after which proteins were extracted using a modified version of the protocol described by Shen et al. (2003). Seeds (2 g samples) were homogenized in pre-cooled extraction buffer $(20 \mathrm{mM}$ Tris- $\mathrm{HCl}, \mathrm{pH} 7.5$, $250 \mathrm{mM}$ sucrose, $10 \mathrm{mM}$ EGTA, $1 \mathrm{mM}$ PMSF, $1 \mathrm{mM}$ DTT and $1 \%$ Triton $\mathrm{X}-100)$ on ice. The homogenate was transferred to a $2 \mathrm{~mL}$ centrifuge tube and centrifuged $(15,000 \mathrm{~g}$, $\left.4{ }^{\circ} \mathrm{C}, 20 \mathrm{~min}\right)$. The supernatant was collected and proteins were precipitated for $30 \mathrm{~min}$ in an ice bath by adding 50\% cold trichloroacetic acid (TCA) until the final concentration of TCA was 10\% (Yang et al., 2006). The supernatant was discarded after centrifugation $\left(15,000 \mathrm{~g}, 4^{\circ} \mathrm{C}, 20 \mathrm{~min}\right)$ and the pellet was then washed four times using cold acetone containing $13 \mathrm{mM}$ DTT. After further centrifugation $\left(15,000 \mathrm{~g}, 4^{\circ} \mathrm{C}, 20 \mathrm{~min}\right)$, the pellet was vacuum-dried. The dried powder was dissolved in sample buffer (7 M urea, $2 \mathrm{M}$ thiourea, 4\% Chaps, 2\% Bio-Lyte pH 3-10, $1 \mathrm{mM}$ PMSF and 1\% DTT; $1 \mathrm{mg}$ dried powder/0.1 mL of buffer) at $4{ }^{\circ} \mathrm{C}$ overnight. Following a final centrifugation $\left(15,000 \mathrm{~g}, 4{ }^{\circ} \mathrm{C}, 20 \mathrm{~min}\right)$, the supernatant was used for 2-DE. Protein concentrations were determined by a dyebinding method (Bradford, 1976). Since some of the components of the sample buffer interfered with the Bradford assay an equal volume of sample buffer was added to the protein reagent to compensate for this interference. Bovine serum albumin was used as the standard.

\section{Two-dimensional electrophoresis}

Isoelectric focusing (IEF) was done using a Bio-Rad PROTEAN electrophoresis system and $17 \mathrm{~cm}$ immobilized IPG dry gel strips with a linear $\mathrm{pH}$ range $(\mathrm{pH} 4-7)$ (BioRad, USA). Protein samples $(\sim 1.5 \mathrm{mg})$ were loaded during the rehydration step (passive rehydration, room temperature, 12-13 h) and IEF was done at 300, 500 and $1000 \mathrm{~V}$ for $1 \mathrm{~h}$, with linear ramping to $8000 \mathrm{~V}$ over $2 \mathrm{~h}$ and holding at $8000 \mathrm{~V}$ until a total voltage of $50 \mathrm{kVh}$ was achieved. Subsequently, the strips were equilibrated for $15 \mathrm{~min}$ with buffer I (6 M urea, $50 \mathrm{mM}$ Tris-HCl, $\mathrm{pH} 6.8,30 \%$ v/v glycerol, $2.5 \% \mathrm{SDS}, 1 \% \mathrm{w} / \mathrm{v}$ DTT) and then for $15 \mathrm{~min}$ with buffer II (6 M urea, $50 \mathrm{mM}$ Tris-HCl, pH 6.8, 30\% v/v glycerol, $2.5 \% \mathrm{SDS}, 2.5 \% \mathrm{w} / \mathrm{v}$ iodoacetamide). After equilibration, the second dimension SDS-PAGE was done using $12 \%$ polyacrylamide gels. Proteins were detected by staining the gels with $0.116 \%$ Coomassie brilliant blue R-250.

\section{Image and data analysis}

The 2-DE gels were scanned (resolution: $300 \mathrm{dpi}$ ) with an ImageScanner III scanner (GE Healthcare BIOScience) and the gel images were analyzed with PDQuest software (Bio-Rad, USA). Each protein spot in the 2-DE map was assigned a number.

\section{In-gel digestion and MALDI-TOF MS analysis}

Protein spots were excised manually from the Coomassie blue-stained gels and each gel fragment was im- mersed in purified water and sonicated twice (10 min each). Subsequently, the gel pieces were destained with $50 \mathrm{mM}$ ammonium bicarbonate and an equivalent volume of $50 \%$ acetonitrile, followed by sequential washing with $25 \mathrm{mM}$ ammonium bicarbonate, 50\% acetonitrile and 100\% acetonitrile, respectively. After lyophilization, the gel fragments were rehydrated in digestion buffer $(2 \mu \mathrm{L})$ containing $25 \mathrm{mM} \mathrm{NH} \mathrm{NCO}_{3}$ and $10 \mathrm{ng}$ of trypsin/ $\mu \mathrm{L}$ (Promega, Madison, WI, USA) at $4{ }^{\circ} \mathrm{C}$. After $30 \mathrm{~min}$, $10-15 \mu \mathrm{L}$ of $25 \mathrm{mM} \mathrm{NH}_{4} \mathrm{HCO}_{3}$ was added and digestion was continued at $37{ }^{\circ} \mathrm{C}$ overnight (11-16 h). After digestion, the peptide solution was collected and tryptic peptide masses were determined using a MALDI-TOF mass spectrometer (Ultraflex-TOF-TOF, Bruker, Germany).

\section{Database search and protein identification}

All of the acquired peptide mass fingerprint data were used in online searches with the Mascot program through Biotechnology Information nonredundant database. The search parameters included trypsin as the selected enzyme (one missed cleavage was permitted), carbamidomethyl as the fixed modification, Gln- > pyro-Glu (N-terminal Q) as the variable modification and a peptide tolerance of $\pm 0.2 \mathrm{Da}$. O. sativa was selected as the taxonomic category. Proteins with a MOWSE score $>64$ were considered as positive identifications.

\section{Bioinformatics analysis of the identified proteins}

The hydropathy of all proteins identified with a high level of confidence (MOWSE scores $>64$ ) and the grand average of hydropathicity (GRAVY) for all the proteins were calculated as described by Kyte and Doolittle (1982), using the Protparam tool from the ExPASy site. The resulting grand average hydropathy values were then analyzed with Origin 7.0 software.

The Gene Ontology (GO) identity of each of the identified proteins was obtained by InterProscan searching. The GO classification of these proteins was obtained using the WEGO platform and the annotated data of the identified proteins.

\section{Results}

\section{Proteomic profile of rice seeds}

The analysis of 2-DE gels with PDQuest software detected 480 reproducible protein spots, most of which were distributed near the center of the gels (Figure 1). For example, the pI of 415 protein spots was between 5 and 7 and accounted for $84.5 \%$ of the total number of protein spots. In addition, the molecular mass of $\sim 90 \%$ of the proteins was between $15 \mathrm{kDa}$ and $95 \mathrm{kDa}$.

\section{Protein identification by MALDI-TOF MS}

A comprehensive knowledge of rice seed proteins will greatly enhance our understanding and exploration of 


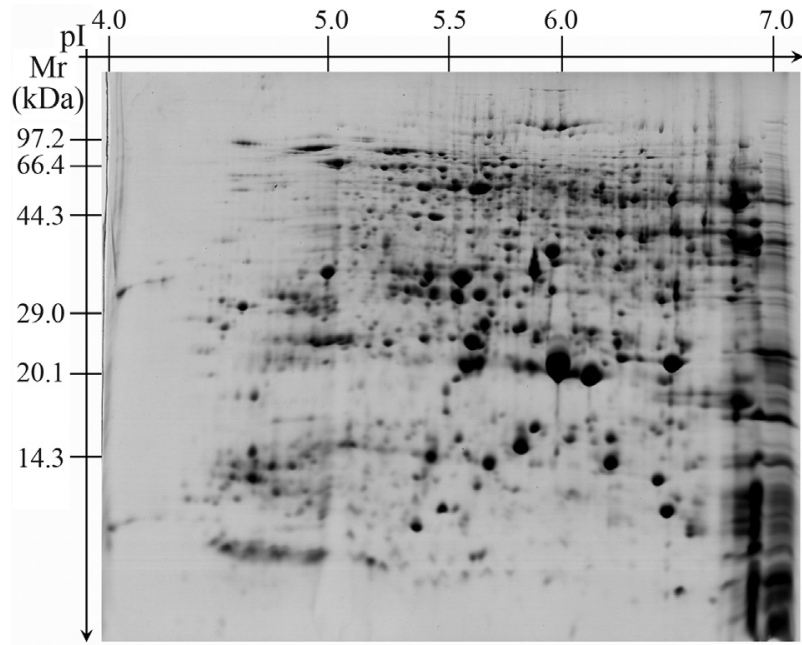

Figure 1 - Proteome profile of rice seeds.

the functional characteristics of these seeds. The 480 reproducible proteins were screened by MALDI-TOF-MS to obtain peptide mass fingerprint data. Only 302 proteins (Figure 2) with high confidence levels (MOWSE scores > 64) were identified (Table S1 - Supplementary Material), of which 52 were unidentified proteins of unknown functions (Figure 3; Table S2 - Supplementary Material). In some cases, different spots contained the same protein (Table S1), e.g., spots 4, 5, 6 and 7 corresponded to hypothetical protein OsJ_13773, and spots 10 and 11 were putative aconitate hydratase.

\section{Classification of protein functions}

The 302 identified proteins represented the products of 252 different genes and were classified into 12 categories based on their functions (Figure 4) (Bevan et al., 1998). Protein functions were retrieved online as Gene Ontology

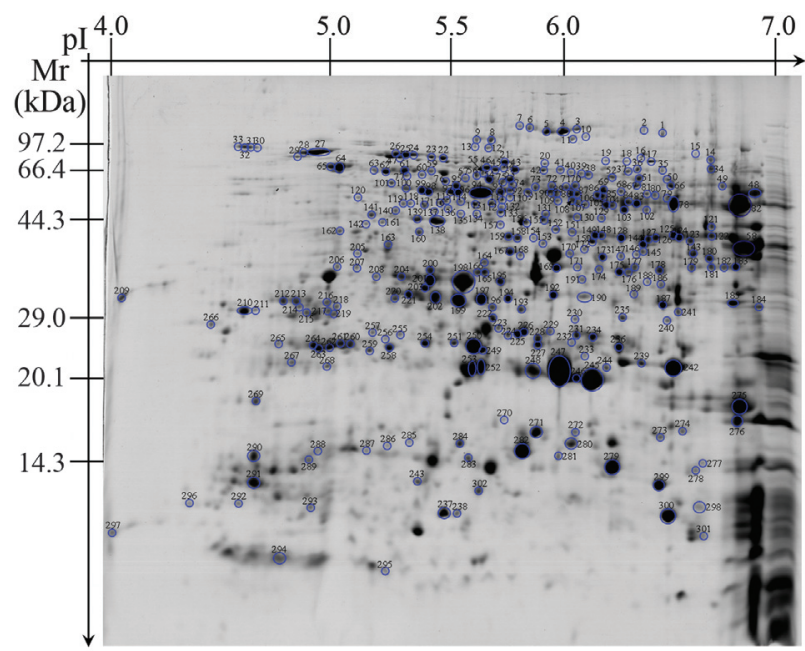

Figure 2 - The protein spots identified by MALDI-TOF-MS. Each protein with a high confidence level (MOWSE score $>64$ ) was assigned a number.

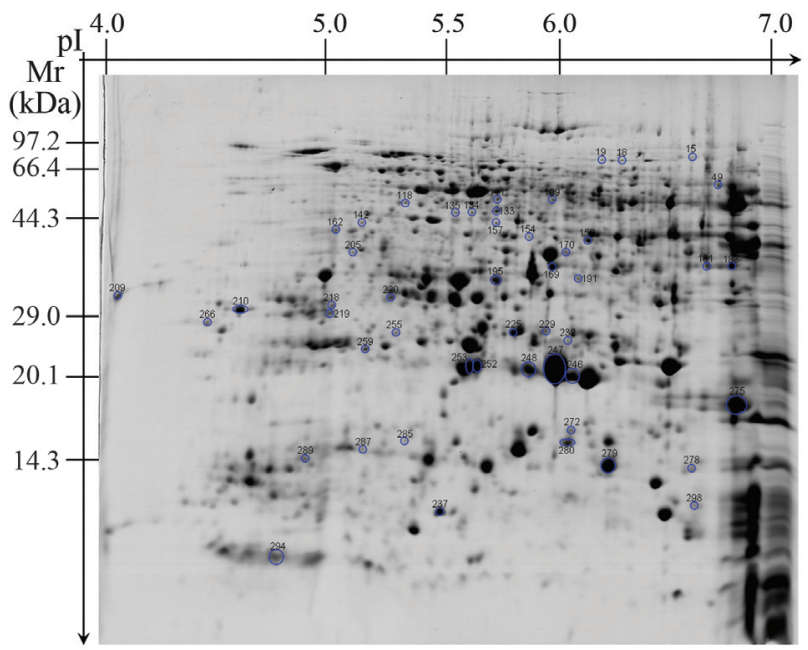

Figure 3 - The unknown proteins identified by MALDI-TOF-MS.

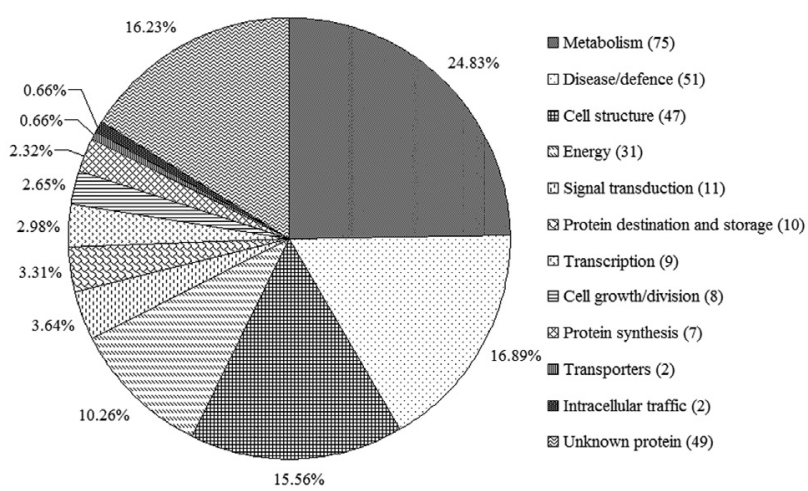

Figure 4 - Functional classifications of the identified proteins. The number of proteins in each category is indicated in parentheses.

information. The 12 categories were: Metabolism (1), Disease/defense (2), Cell structure (3), Energy (4), Signal transduction (5), Protein destination and storage (6), Cell growth/division (7), Protein synthesis (8), Transcription (9), Transporters (10), Intracellular traffic (11) and Unknown protein (12). The functional categories were determined according to Bevan et al. (1998). As shown in Figure 4,75 spots were involved in metabolic processes and were the most abundant category (24.8\%). Proteins related to disease/defense were the second most abundant category $(16.9 \%)$ and unknown proteins were the third most abundant $(16.2 \%)$.

\section{Bioinformatics analysis of identified proteins}

Proteins with negative GRAVY scores were hydrophilic and those with positive GRAVY scores were hydrophobic. Figure 5 shows that identified proteins with negative GRAVY scores were significantly more abundant than those with positive GRAVY scores. The GRAVY values of most proteins were between -0.6 and 0 , indicating that most of them were hydrophilic. 


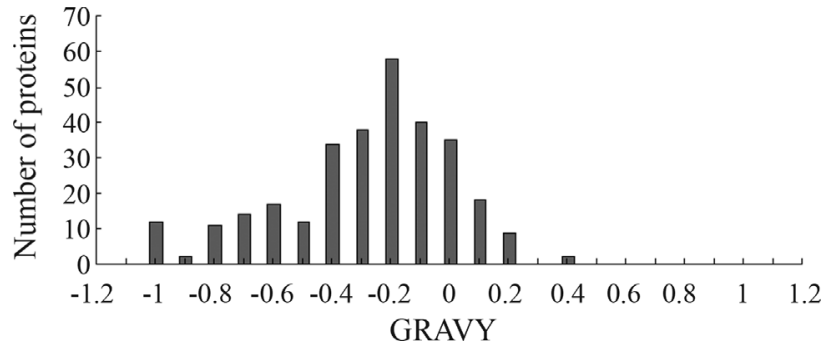

Figure 5 - Hydropathic analysis of all proteins identified by 2-DE. Negative and positive GRAVY values indicate hydrophilic and hydrophobic proteins, respectively.

Figure 6 shows the GO analysis of the identified proteins, all of which were classified in terms of cellular component, molecular function, and physiological and biological processes using appropriate software (Gene Ontology Annotation Plot, WEGO). Most of the identified proteins associated with cellular components were involved in cell, cell parts, envelope, macromolecular complex, organelle and organelle parts, while those associated with molecular functions were involved in antioxidant, binding, catalytic, electron carrier, enzyme regulator, nutrient reservoir, transcription regulator and transporter activities. Biological processes involved biological regulation, cellular component organization, cellular process, establishment of localization, localization, metabolic process, multi/-organism process, multicellular organismal process, pigmentation, reproduction, reproductive process and response to stimulus.

\section{Discussion}

Proteomic technologies are the most widely applied approach for identifying proteins in rice (Yang et al., 2006, 2007a,b; Chitteti and Peng, 2007; Torabi et al., 2009; Chi et al., 2010; Fan et al., 2011; He et al., 2011; Nwugo and Huerta, 2011; Ding et al., 2012). In this study, we used 2-DE combined with MALDI-TOF-MS to obtain a 2-DE proteomic profile of rice seeds. A total of 480 reproducible

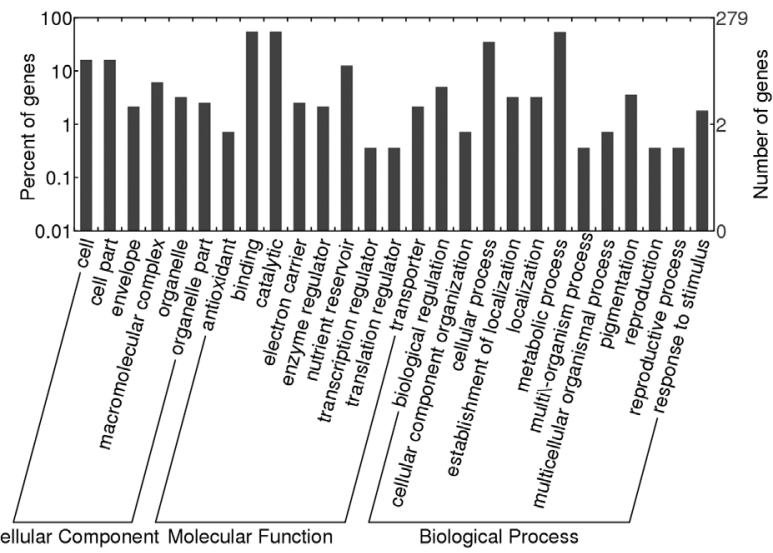

Figure 6 - GO classifications of the identified proteins. All of the proteins were classified into three main categories and 26 subcategories. protein spots were selected for MALDI-TOF-MS analysis. However, only 302 proteins with a MOWSE score $>64$ were identified as proteins (see Tables S1 and S2); there were no significant matches for the other 178 protein spots. There are at least two possible explanations for this phenomenon. First, some protein spots with low confidence levels possibly contained more than one protein. Second, some small protein spots could not be identified by MALDI-TOF-MS or were not included in the databases because of a lack of information in the rice database (Woo et al., 2002).

The majority of corn proteins can be divided into three categories: storage proteins, structure- or metabolism-related proteins, and protective proteins (Shewry and Halford, 2002). As shown in Figure 4, 24.8\% of the identified proteins were classified in the metabolism group, $16.9 \%$ were involved in disease/defense and $15.6 \%$ were cell structure proteins. Furthermore, $10.3 \%$ of the identified proteins were classified in the energy group. Together, the proteins in these groups accounted for $>67 \%$ of the identified proteins. Metabolism is essential for many activities and, not surprisingly, metabolism-related proteins have an important role in maintaining seed vigor. In addition, most metabolism- and energy-related proteins are associated with carbohydrate metabolic pathways (He et al., 2011), including glycolysis and the TCA cycle. In this study, many enzymes involved in glycolysis were identified, including pyruvate orthophosphate dikinase (spots 12 and 13), phosphoglucomutase (spot 21), pyrophosphate-fructose-6phosphate 1-phosphotransferase (spot 51), pyrophosphate-fructose-6-phosphate 2-phosphotransferase (spot 52), UTP-glucose-1-phosphate uridylyltransferase (spots 56 and 97), fructose bisphosphate aldolase (spot 58), glucose6-phosphate isomerase (spots 60 and 77), enolase (spots 94 and 95), glyceraldehyde 3-phosphate dehydrogenase (spots 143 and 145), glucose-6-phosphate 1-epimerase (spot 161) and triosephosphate isomerase (spots 250, 254, 256 and 257). Some enzymes involved in the TCA cycle were also identified, such as aconitate hydratase (spots 10 and 11), succinate dehydrogenase (spot 35), isocitrate dehydrogenase (spot 121), succinyl-CoA synthetase (spot 160) and malate dehydrogenase (spots 167, 168 and 173). Similarly, two enzymes involved in the alcoholic fermentation pathway were also identified, namely, alcohol dehydrogenase (spot 34) and pyruvate decarboxylase (spot 45). These results indicate that aerobic and anaerobic respiration occurs in storage rice seeds. The energy demand is met primarily by glycolysis and the TCA cycle, although anaerobic fermentation can also provide energy in the absence of oxygen.

We also identified 12 proteins related to amino acid metabolism: five of these have a central role in amino acid metabolism (spots 106, 148, 153, 155 and 156), four are involved in the metabolism of branched chain amino acids (spots 38, 40, 53 and 141) and the remaining three are in- 
volved in arginine metabolism (spots 105, 107 and 108). Compared with germinating rice seeds, there were fewer proteins associated with amino acid metabolism in storage rice seeds. There are several explanations for this phenomenon. First, dry seeds are used mainly for storage and transport, and a lower metabolic activity favors the preservation of rice seeds. Second, the moisture content of storage seeds is very low, with the existing metabolism providing only essential energy and many physiological and biochemical reactions are inactive. Third, staining with Coomassie brilliant blue may not be sufficiently sensitive to detect some spots so that more sensitive staining methods such as negative staining and fluorescence staining should be used in future studies. Finally, some strongly basic proteins or proteins with extreme molecular masses may be missed in the 2-DE gels. The presence of the same protein in different spots suggests variations in post-translational modifications or the presence of protein subunits, as also suggested by others (Yang et al., 2006; Chi et al., 2010; Liu and Bennett, 2011).

The hydropathy analysis showed that most of the rice seed proteins were hydrophilic. Rice seeds contain many proteins and enzymes related to metabolism and disease/defense, and these proteins may only be active in physiological processes when in solution, i.e., in a soluble state. The presence of soluble proteins is a further characteristic of rice seed proteins.

In a proteomic survey of metabolic pathways in rice, Koller et al. (2002) identified 2,528 unique proteins, 877 of which were from seeds. Of the 2,528 proteins detected, 189 were expressed in rice leaves, roots and seeds. In addition, there were 512 seed-specific proteins. Koller et al. (2002) collected their seed samples from the entire panicle at 14 days postanthesis. In contrast, we used seed samples from mature rice seeds and identified 302 proteins that represented 252 gene products. Our findings therefore expand the results of previous studies.

\section{Conclusion}

Seeds are a major food source for humans and are essential for plant reproduction. In this study, we identified 302 proteins in the proteome of rice seeds. These proteins represented 252 gene products and were classified into 12 functional categories. The 302 proteins identified here represent an important contribution to the rice proteome database and shed light on the protein content of rice seeds.

\section{Acknowledgments}

This work was supported by the Ministry of Agriculture Transgenic Major Project (grant 2009ZX08012018B), National Natural Science Foundation of China (grant 31201189), the Scientific Research Promotion Fund for the Talents of Jiangsu University (grant 11JDG049) and
Postdoctoral Fund of Department of Personnel of Jiangsu Province (grant 1102010C).

\section{References}

Agrawal GK and Rakwal R (2011) Rice proteomics: A move toward expanded proteome coverage to comparative and functional proteomics uncovers the mysteries of rice and plant biology. Proteomics 11:1630-1649.

Agrawal GK, Jwa NS, Iwahashi Y, Yonekura M, Iwahashi H and Rakwal R (2006) Rejuvenating rice proteomics: Facts, challenges, and visions. Proteomics 6:5549-5576.

Ahrné E, Ohta Y, Nikitin F, Scherl A, Lisacek F and Müller M (2011) An improved method for the construction of decoy peptide MS/MS spectra suitable for the accurate estimation of false discovery rates. Proteomics 11:4085-4095.

Bevan M, Bancroft I, Bent E, Love K, Goodman H, Dean C, Bergkamp R, Dirkse W, Van Staveren M, Stiekema W, et al. (1998) Analysis of 1.9 Mb of contiguous sequence from chromosome 4 of Arabidopsis thaliana. Nature 391:485488.

Bradford MM (1976) A rapid and sensitive method for the quantitation of microgram quantities of protein utilizing the principle of protein-dye binding. Anal Biochem 72:248-254.

Chi F, Yang P, Han F, Jing Y and Shen S (2010) Proteomic analysis of rice seedlings infected by Sinorhizobium meliloti 1021. Proteomics 10:1861-1874.

Chitteti BR and Peng Z (2007) Proteome and phosphoproteome differential expression under salinity stress in rice (Oryza sativa) roots. J Proteome Res 6:1718-1727.

Ding C, You J, Wang S, Liu Z, Li G, Wang Q and Ding Y (2012) A proteomic approach to analyze nitrogen- and cytokininresponsive proteins in rice roots. Mol Biol Rep 39:16171626.

Fan W, Cui W, Li X, Chen S, Liu G and Shen S (2011) Proteomics analysis of rice seedling responses to ovine saliva. J Plant Physiol 168:500-509.

Finch-Savage WE and Leubner-Metzger G (2006) Seed dormancy and the control of germination. New Phytol 171:501-523.

He D, Han C, Yao J, Shen S and Yang P (2011) Constructing the metabolic and regulatory pathways in germinating rice seeds through proteomic approach. Proteomics 11:2693-2713.

Jugran A, Bhatt ID and Rawal RS (2010) Characterization of agro-diversity by seed storage protein electrophoresis: Focus on rice germplasm from Uttarakhand Himalaya, India. Rice Sci 17:122-128.

Kalli A and Hess S (2012) Effect of mass spectrometric parameters on peptide and protein identification rates for shotgun proteomic experiments on an LTQ-orbitrap mass analyzer. Proteomics 12:21-31.

Koller A, Washburn MP, Lange BM, Andon NL, Deciu C, Haynes PA, Hays L, Schieltz D, Ulaszek R, Wei J, et al. (2002) Proteomic survey of metabolic pathways in rice. Proc Natl Acad Sci USA 99:11969-11974.

Koornneef M, Bentsink L and Hilhorst H (2002) Seed dormancy and germination. Curr Opin Plant Biol 5:33-36.

Kyte J and Doolittle RF (1982) A simple method for displaying the hydropathic character of a protein. J Mol Biol 157:105132. 
Li X, Bai H, Wang X, Li L, Cao Y, Wei J, Liu Y, Liu L, Gong X, $\mathrm{Wu} \mathrm{L}$, et al. (2011) Identification and validation of rice reference proteins for western blotting. J Exp Bot 62:47634772 .

Liu JX and Bennett J (2011) Reversible and irreversible droughtinduced changes in the anther proteome of rice (Oryza sativa L.) genotypes IR64 and Moroberekan. Mol Plant 4:59-69.

Liu Q and Xue Q (2006) Genome sequencing and identification of gene function in rice. Acta Genet Sin 33:669-677.

Nwugo CC and Huerta AJ (2011) The effect of silicon on the leaf proteome of rice (Oryza sativa L.) plants under cadmiumstress. J Proteome Res 10:518-528.

Sasaki T and Burr B (2000) International Rice Genome Sequencing Project: The effort to completely sequence the rice genome. Curr Opin Plant Biol 3:138-141.

Shen S, Jing Y and Kuang T (2003) Proteomics approach to identify wound-response related proteins from rice leaf sheath. Proteomics 3:527-535.

Shewry PR and Halford NG (2002) Cereal seed storage proteins: Structures, properties and role in grain utilization. J Exp Bot 53:947-958.

Torabi S, Wissuwa M, Heidari M, Naghavi MR, Gilany K, Hajirezaei MR, Omidi M, Yazdi-Samadi B, Ismail AM and Salekdeh GH (2009) A comparative proteome approach to decipher the mechanism of rice adaptation to phosphorous deficiency. Proteomics 9:159-170.

Vaughan D, Lu BR and Tomooka N (2008) Was Asian rice (Oryza sativa) domesticated more than once? Rice 1:16-24.

Wang Y, Kim S, Kim S, Agrawal G, Rakwal R and Kang K (2011) Biotic stress-responsive rice proteome: An overview. J Plant Biol 54:219-226.

Wilkins MR, Gasteiger E, Tonella L, Ou K, Tyler M, Sanchez JC, Gooley AA, Walsh BJ, Bairoch A, Appel RD, et al. (1998) Protein identification with $\mathrm{N}$ and C-terminal sequence tags in proteome projects. J Mol Biol 278:599-608.

Woo SH, Fukuda M, Islam N, Takaoka M, Kawasaki H and Hirano H (2002) Efficient peptide mapping and its application to identify embryo proteins in rice proteome analysis. Electrophoresis 23:647-654
Yang P, Liang Y, Shen S and Kuang T (2006) Proteome analysis of rice uppermost internodes at the milky stage. Proteomics 6:3330-3338

Yang P, Chen H, Liang Y and Shen S (2007a) Proteomic analysis of de-etiolated rice seedlings upon exposure to light. Proteomics 7:2459-2468.

Yang P, Li X, Wang X, Chen H, Chen F and Shen S (2007b) Proteomic analysis of rice (Oryza sativa) seeds during germination. Proteomics 7:3358-3368.

Yang MF, Liu YJ, Liu Y, Chen H, Chen F and Shen SH (2009) Proteomic analysis of oil mobilization in seed germination and postgermination development of Jatropha curcas. J Proteome Res 8:1441-1451.

\section{Internet Resources}

MASCOT database, Matrix Science, London, UK, http://www.matrixscience.com (accessed on September 2, 2011).

ExPASy, http://www.expasy.ch/tools/protparam.html (accessed on April 17, 2012).

InterProscan, http://www.ebi.ac.uk/Tools/InterProScan (accessed on March 19, 2012).

WEGO program for Gene Ontology classification, http://wego.genomics.org.cn (accessed on April 12, 2012).

Gene Ontology, http://www.geneontology.org (accessed on April 12, 2012)

\section{Supplementary Material}

The following online material is available for this article:

Table S1 - The protein spots identified by MALDI-TOF-MS.

Table S2 - The unknown proteins identified by MALDI-TOF-MS.

This material is available as part of the online article from http://www.scielo.br/gmb.

Associate Editor: Marcia Pinheiro Margis

License information: This is an open-access article distributed under the terms of the Creative Commons Attribution License, which permits unrestricted use, distribution, and reproduction in any medium, provided the original work is properly cited. 
Table S1 - The protein spots identified by MALDI-TOF-MS.

\begin{tabular}{|c|c|c|c|c|c|c|c|}
\hline $\begin{array}{l}\text { Protein } \\
\text { no. }\end{array}$ & Protein name & Accession no. & $\begin{array}{l}\text { MOWSE } \\
\text { score }\end{array}$ & $\mathrm{NMP}^{\mathrm{a}}$ & $\mathrm{SC}^{\mathrm{b}}$ & $\begin{array}{l}\text { Theoretical } \mathrm{Mr} \\
(\mathrm{kDa}) \text { and } \mathrm{pI}\end{array}$ & Function $^{c}$ \\
\hline 2 & elongation factor 2 & NP_001046972 & 71 & 12 & $19 \%$ & $94.99 / 5.85$ & 8 \\
\hline 4 & hypothetical protein OsJ_13773 & EEE60487 & 364 & 35 & $50 \%$ & $100.41 / 5.58$ & 1 \\
\hline 5 & hypothetical protein OsJ_13773 & EEE60487 & 388 & 43 & $50 \%$ & $100.41 / 5.58$ & 1 \\
\hline 6 & hypothetical protein OsJ_13773 & EEE60487 & 350 & 32 & $46 \%$ & $100.41 / 5.58$ & 1 \\
\hline 9 & hypothetical protein OsI_19920 & EEC79204 & 170 & 23 & $33 \%$ & $94.33 / 5.37$ & 5 \\
\hline 10 & putative aconitate hydratase, cytoplasmic & Q6YZX6 & 214 & 23 & $35 \%$ & $98.59 / 5.67$ & 1 \\
\hline 11 & putative aconitate hydratase, cytoplasmic & Q6YZX6 & 272 & 33 & $47 \%$ & $98.59 / 5.67$ & 1 \\
\hline 12 & pyruvate orthophosphate dikinase & NP_001050430 & 276 & 30 & $47 \%$ & $87.70 / 5.37$ & 1 \\
\hline 13 & pyruvate orthophosphate dikinase & NP_001050430 & 116 & 16 & $23 \%$ & $87.70 / 5.37$ & 1 \\
\hline 18 & hypothetical protein OsJ_11969 & EEE59627 & 65 & 4 & $26 \%$ & $13.99 / 4.99$ & 12 \\
\hline 19 & hypothetical protein & BAD20105 & 64 & 7 & $31 \%$ & $30.32 / 11.81$ & 12 \\
\hline 20 & OSJNBa0039C07.11 & CAE05155 & 88 & 14 & $26 \%$ & $75.38 / 5.83$ & 3 \\
\hline 21 & phosphoglucomutase & NP_001051066 & 310 & 31 & $64 \%$ & $63.14 / 5.4$ & 4 \\
\hline 22 & heat shock cognate $70 \mathrm{kDa}$ protein & ABF95267 & 247 & 28 & $47 \%$ & $71.93 / 5.3$ & 2 \\
\hline 23 & heat shock cognate $70 \mathrm{kDa}$ protein & ABF95267 & 150 & 23 & $52 \%$ & $71.93 / 5.3$ & 2 \\
\hline 24 & endosperm lumenal binding protein & AAB63469 & 128 & 19 & $29 \%$ & $73.67 / 5.3$ & 3 \\
\hline 25 & endosperm lumenal binding protein & AAB63469 & 211 & 21 & $36 \%$ & $73.67 / 5.3$ & 3 \\
\hline
\end{tabular}


endosperm lumenal binding protein

hypothetical protein OsI_37938

hypothetical protein OsI_37938

protein disulfide-isomerase A1

Os $10 \mathrm{~g} 0505900$

Os $10 \mathrm{~g} 0505900$

Os $10 \mathrm{~g} 0505900$

Os $10 \mathrm{~g} 0505900$

alcohol dehydrogenase

succinate dehydrogenase (ubiquinone) flavoprotein subunit aspartyl-tRNA synthetase

hypothetical protein OsJ_16432

2-isopropylmalate synthase B

putative $\beta$-N-acetylhexosaminidase

2-isopropylmalate synthase

Os03g0214000

asparaginyl-tRNA synthetase

pyruvate decarboxylase 2

hypothetical protein OsJ_07413

pyruvate decarboxylase

hypothetical protein OsI_04213

heat shock $70 \mathrm{kDa}$ protein $1 / 8$

putative globulin

Os02g0250600

hypothetical protein OsI_30268

pyrophosphate-fructose-6-phosphate 1-phosphotransferase pyrophosphate-fructose-6-phosphate 2-phosphotransferase

ketol-acid reductoisomerase

Chain A, ketol-acid reductoisomerase

$\begin{array}{lccc}\text { AAB63469 } & 199 & 21 & 33 \% \\ \text { EEC69073 } & 184 & 19 & 37 \% \\ \text { EEC69073 } & 146 & 18 & 29 \% \\ \text { NP_001045579 } & 113 & 13 & 28 \% \\ \text { NP_001065009 } & 70 & 7 & 17 \% \\ \text { NP_001065009 } & 121 & 12 & 31 \% \\ \text { NP_001065009 } & 170 & 18 & 42 \% \\ \text { NP_001065009 } & 128 & 15 & 34 \% \\ \text { NP_001067484 } & 109 & 14 & 42 \% \\ \text { NP_001058845 } & 169 & 18 & 40 \% \\ \text { NP_001047770 } & 165 & 17 & 35 \% \\ \text { EEE61811 } & 166 & 16 & 40 \% \\ \text { ABA91408 } & 174 & 19 & 40 \% \\ \text { AAT77374 } & 106 & 15 & 33 \% \\ \text { NP_001066116 } & 151 & 17 & 35 \% \\ \text { NP_001049368 } & 156 & 15 & 36 \% \\ \text { NP_001043066 } & 199 & 23 & 40 \% \\ \text { AAA90948 } & 204 & 17 & 37 \% \\ \text { EAZ23710 } & 70 & 8 & 19 \% \\ \text { NP_001049811 } & 210 & 17 & 40 \% \\ \text { EEC71703 } & 148 & 17 & 37 \% \\ \text { NP_001044757 } & 170 & 25 & 42 \% \\ \text { AAS07324 } & 124 & 14 & 30 \% \\ \text { NP_001046445 } & 64 & 9 & 22 \% \\ \text { EAZ08004 } & 118 & 17 & 34 \% \\ \text { NP_001057284 } & 233 & 23 & 52 \% \\ \text { NP_001057284 } & 238 & 24 & 55 \% \\ \text { NP_001043738 } & 103 & 10 & 31 \% \\ \text { 3FR7_A } & 159 & 17 & 45 \% \\ \end{array}$

$73.67 / 5.3$

$76.45 / 5.11$

$76.45 / 5.11$

$62.44 / 4.76$

$45.55 / 4.74$

$45.55 / 4.74$

$45.55 / 4.74$

$45.55 / 4.74$

$41.70 / 6.2$

$69.49 / 6.61$

$61.45 / 5.99$

$57.26 / 5.74$

$68.86 / 6.46$

$59.01 / 5.71$

$68.87 / 6.46$

$68.72 / 5.88$

$62.95 / 5.68$

$65.34 / 5.9$

$59.74 / 9.83$

$65.76 / 5.53$

$60.95 / 5.36$

$71.31 / 5.1$

$63.85 / 8.35$

47.34/6.4

$64.24 / 6.59$

61.91/6.01

61.91/6.01

$59.99 / 5.73$

$57.57 / 5.46$ 
enolase

UTP-glucose-1-phosphate uridylyltransferase

Chain A, ketol-acid reductoisomerase

fructose-bisphosphate aldolase, class I

chaperonin GroEL

glucose-6-phosphate isomerase

Os06g0114000

$60 \mathrm{kDa}$ chaperonin $\alpha$ subunit

$60 \mathrm{kDa}$ chaperonin $\alpha$ subunit

protein disulfide isomerase

protein disulfide isomerase

granule-bound starch synthase 1

granule-bound starch synthase 1

UDP glucose 6-dehydrogenase

ATP synthase F0 subunit 1

hypothetical protein OsI_38072

ATP synthase F0 subunit 1

putative selenium binding protein

prolyl aminopeptidase 2

inositol-3-phosphate synthase

glucose-1-phosphate adenylyltransferase large chain

hypothetical protein OsI_10505

glucose-6-phosphate isomerase

alanine transaminase

alanine transaminase

glutathione reductase (NADPH)

putative inosine monophosphate dehydrogenase

Os03g0793700

alanine transaminase

$\begin{array}{lccc}\text { ABB46862 } & 79 & 8 & 26 \% \\ \text { NP_001063879 } & 197 & 15 & 52 \% \\ \text { 3FR7_A } & 110 & 12 & 34 \% \\ \text { NP_001045130 } & 92 & 9 & 33 \% \\ \text { NP_001064784 } & 112 & 13 & 32 \% \\ \text { NP_001063415 } & 101 & 15 & 27 \% \\ \text { NP_001056601 } & 168 & 17 & 37 \% \\ \text { AAP44754 } & 281 & 23 & 59 \% \\ \text { AAP44754 } & 75 & 23 & 27 \% \\ \text { BAA92322 } & 76 & 10 & 34 \% \\ \text { BAA92322 } & 197 & 17 & 59 \% \\ \text { AEB52353 } & 79 & 7 & 26 \% \\ \text { AEB52353 } & 185 & 19 & 59 \% \\ \text { NP_00105132 } & 184 & 21 & 57 \% \\ \text { YP_002000594 } & 234 & 26 & 57 \% \\ \text { EAY82861 } & 80 & 10 & 35 \% \\ \text { YP_002000594 } & 207 & 24 & 49 \% \\ \text { BAB40923 } & 139 & 17 & 51 \% \\ \text { Q6K669 } & 128 & 19 & 38 \% \\ \text { ABF94421 } & 76 & 9 & 35 \% \\ \text { BAD68891 } & 165 & 16 & 34 \% \\ \text { EAY89022 } & 104 & 11 & 29 \% \\ \text { BAD08451 } & 196 & 23 & 43 \% \\ \text { NP_001064504 } & 258 & 28 & 52 \% \\ \text { NP_001064504 } & 217 & 20 & 46 \% \\ \text { NP_001048485 } & 118 & 15 & 41 \% \\ \text { AAK09225 } & 115 & 13 & 39 \% \\ \text { NP_001051533 } & 200 & 19 & 38 \% \\ \text { NP_001064504 } & 112 & 12 & 30 \%\end{array}$

$\begin{array}{cc}51.89 / 5.72 & 3 \\ 51.82 / 5.43 & 1 \\ 57.57 / 5.46 & 3 \\ 39.14 / 8.35 & 4 \\ 61.10 / 5.71 & 3 \\ 68.84 / 5.71 & 4 \\ 64.33 / 5.6 & 3 \\ 61.48 / 5.36 & 3 \\ 61.48 / 5.36 & 3 \\ 33.50 / 4.81 & 6 \\ 33.50 / 4.81 & 6 \\ 45.35 / 6.14 & 4 \\ 45.35 / 6.14 & 4 \\ 53.44 / 5.79 & 4 \\ 55.62 / 5.85 & 10 \\ 32.83 / 8.61 & 5 \\ 55.62 / 5.85 & 10 \\ 51.33 / 5.73 & 3 \\ 62.18 / 8.29 & 6 \\ 44.41 / 5.38 & 2 \\ 57.74 / 5.48 & 1 \\ 58.83 / 5.5 & 6 \\ 68.77 / 5.88 & 1 \\ 53.13 / 6.23 & 4 \\ 53.13 / 6.23 & 4 \\ 53.87 / 6.24 & 1 \\ 52.85 / 6.03 & 1 \\ 52.44 / 6.78 & 2 \\ 53.13 / 6.23 & 4\end{array}$

NP_001064504

$53.13 / 6.23$ 
alanine transaminase

aldehyde dehydrogenase $\left(\mathrm{NAD}^{+}\right)$

glucose-1-phosphate adenylyltransferase

aldehyde dehydrogenase $\left(\mathrm{NAD}^{+}\right)$

glucose-1-phosphate adenylyltransferase

retrotransposon protein

wheat adenosylhomocysteinase-like protein

hypothetical protein OsI_25188

2-phospho-D-glycerate hydroylase

hypothetical protein OsI_25188

enolase

enolase

2-phosphoglycerate dehydratase

UTP-glucose-1-phosphate uridylyltransferase

F-type $\mathrm{H}^{+}$-transporting ATPase subunit $\beta$

F-type $\mathrm{H}^{+}$-transporting ATPase subunit $\beta$

F-type $\mathrm{H}^{+}$-transporting ATPase subunit $\beta$

V-type $\mathrm{H}^{+}$-transporting ATPase subunit $\beta$

hypothetical protein OsI_17385

Cupin family protein

6-phosphogluconate dehydrogenase

argininosuccinate synthase

putative aminoacylase

argininosuccinate synthase

argininosuccinate synthase

OSJNBa0052P16.16

glucose-1-phosphate adenylyltransferase

Os05g0418000

translation initiation factor $4 \mathrm{~A}$

$\begin{array}{lccc}\text { NP_001064504 } & 80 & 11 & 19 \% \\ \text { NP_001057358 } & 126 & 16 & 37 \% \\ \text { NP_001061603 } & 86 & 9 & 28 \% \\ \text { NP_001057358 } & 95 & 14 & 26 \% \\ \text { NP_001061603 } & 102 & 11 & 33 \% \\ \text { ABA92141 } & 71 & 17 & 11 \% \\ \text { AAO72664 } & 133 & 16 & 39 \% \\ \text { EEC81650 } & 261 & 24 & 56 \% \\ \text { AAN04181 } & 109 & 9 & 28 \% \\ \text { EEC81650 } & 161 & 18 & 39 \% \\ \text { AAC49173 } & 116 & 15 & 34 \% \\ \text { NP_001049556 } & 179 & 20 & 58 \% \\ \text { Q42971 } & 214 & 24 & 63 \% \\ \text { NP_001063879 } & 195 & 19 & 58 \% \\ \text { NP_001043900 } & 230 & 20 & 49 \% \\ \text { NP_001056261 } & 193 & 17 & 45 \% \\ \text { NP_001056261 } & 212 & 18 & 50 \% \\ \text { NP_001057902 } & 91 & 9 & 28 \% \\ \text { EEC77995 } & 95 & 12 & 24 \% \\ \text { ABF94466 } & 78 & 14 & 13 \% \\ \text { NP_001056586 } & 77 & 21 & 42 \% \\ \text { NP_001066459 } & 66 & 11 & 21 \% \\ \text { BAD10058 } & 64 & 12 & 30 \% \\ \text { NP_001066459 } & 100 & 10 & 24 \% \\ \text { NP_001066459 } & 65 & 14 & 29 \% \\ \text { CAD39715 } & 64 & 6 & 20 \% \\ \text { NP_001051184 } & 68 & 15 & 37 \% \\ \text { NP_001055566 } & 64 & 9 & 28 \% \\ \text { NP_001045878 } & 80 & 8 & 25 \%\end{array}$

$53.13 / 6.23$

$59.61 / 6.33$

$53.20 / 5.87$

$59.61 / 6.33$

$53.20 / 5.87$

$218.17 / 8.75$

$53.86 / 5.62$

$57.60 / 5.98$

$46.20 / 5.16$

$57.60 / 5.98$

$48.30 / 5.42$

$48.29 / 5.32$

$48.29 / 5.41$

$51.82 / 5.43$

$59.60 / 6.1$

$59.01 / 5.95$

$59.01 / 5.95$

$54.14 / 5.07$

$54.50 / 6.44$

$74.70 / 6.02$

$52.97 / 5.85$

$52.50 / 6.59$

49.86/5.88

$52.50 / 6.59$

$52.50 / 6.59$

$48.00 / 6.64$

$55.79 / 7.01$

$50.07 / 5.44$

$47.39 / 5.43$
4
1
1
1
1
3
3
3
3
3
4
4
4
1
4
4
4
4
1
2
1
1
1
1
1
12
8 


$\begin{array}{ll}113 & \text { hypothetical protein OsI_24355 } \\ 114 & \text { amidase, hydantoinase/carbamoylase family protein } \\ 115 & \text { eukaryotic initiation factor 4A } \\ 116 & \text { glucose-1-phosphate adenylyltransferase } \\ 117 & \text { TPA_exp: transposase } \\ 118 & \text { Os10g0188500 } \\ 119 & \text { hypothetical protein OsI_27570 } \\ 120 & \text { hypothetical protein OsI_09330 } \\ 121 & \text { isocitrate dehydrogenase } \\ 122 & \text { alcohol dehydrogenase 1 } \\ 123 & \text { hypothetical protein OsI_18007 } \\ 124 & \text { L-iditol 2-dehydrogenase } \\ 125 & \text { alcohol dehydrogenase 1 } \\ 126 & \text { L-iditol 2-dehydrogenase } \\ 127 & \text { L-iditol 3-dehydrogenase } \\ 128 & \text { L-iditol 4-dehydrogenase } \\ 129 & \text { hypothetical protein OsJ_06802 } \\ 130 & \text { hypothetical protein OsI_05369 } \\ 131 & \text { tryptophanyl-tRNA synthetase } \\ 132 & \text { guanine nucleotide-exchange protein GEP2 } \\ 133 & \text { Os02g0158900 } \\ 134 & \text { Os04g0429200 } \\ 135 & \text { hypothetical protein OsJ_11020 } \\ 136 & \text { OSJNBb0050O03.16 } \\ 137 & \text { monodehydroascorbate reductase } \\ 138 & \text { actin } \\ 139 & \text { actin } \\ 140 & \text { retrotransposon protein } \\ 141 & \text { 3-isopropylmalate dehydrogenase } \\ & \end{array}$

\begin{tabular}{lc} 
EAZ02256 & 123 \\
ABA99240 & 121 \\
BAA02152 & 80 \\
NP_001062808 & 106 \\
DAA02079 & 66 \\
NP_001176052 & 146 \\
EEC82801 & 64 \\
EAY87910 & 86 \\
NP_001043749 & 64 \\
ABA92030 & 64 \\
EEC78293 & 94 \\
NP_001062412 & 70 \\
ABA92030 & 65 \\
NP_001062412 & 98 \\
NP_001062412 & 68 \\
NP_001062412 & 113 \\
EEE57026 & 90 \\
EAY77382 & 95 \\
NP_001066951 & 83 \\
AAM00191 & 105 \\
NP_001045960 & 70 \\
NP_001173940 & 85 \\
EAZ27089 & 66 \\
CAE01726 & 64 \\
BAA77282 & 66 \\
NP_001065830 & 68 \\
NP_001054419 & 86 \\
ABA95357 & 87 \\
NP_001050807 & 85 \\
\hline
\end{tabular}

$\begin{array}{cccc}10 & 38 \% & 48.64 / 5.23 & 8 \\ 8 & 26 \% & 51.80 / 5.41 & 6 \\ 12 & 29 \% & 47.19 / 5.29 & 8 \\ 8 & 24 \% & 55.10 / 6.23 & 1 \\ 9 & 18 \% & 72.82 / 9.31 & 9 \\ 4 & 34 \% & 21.14 / 4.81 & 12 \\ 9 & 10 \% & 131.01 / 8.46 & 7 \\ 16 & 38 \% & 47.04 / 4.94 & 3 \\ 8 & 22 \% & 46.36 / 6.34 & 4 \\ 10 & 22 \% & 38.14 / 6.19 & 2 \\ 10 & 23 \% & 59.89 / 5.58 & 5 \\ 9 & 33 \% & 39.99 / 6.03 & 4 \\ 6 & 14 \% & 38.14 / 6.19 & 2 \\ 16 & 55 \% & 39.99 / 6.03 & 1 \\ 11 & 30 \% & 39.99 / 6.03 & 1 \\ 17 & 55 \% & 39.99 / 6.03 & 1 \\ 5 & 25 \% & 34.307 / 8.1 & 3 \\ 6 & 18 \% & 45.69 / 5.74 & 3 \\ 13 & 37 \% & 46.53 / 5.62 & 9 \\ 13 & 7 \% & 199.20 / 5.49 & 7 \\ 10 & 31 \% & 44.69 / 5.47 & 12 \\ 5 & 31 \% & 15.49 / 6.89 & 12 \\ 4 & 60 \% & 7.64 / 9.76 & 12 \\ 5 & 25 \% & 36.58 / 5.37 & 3 \\ 12 & 50 \% & 43.04 / 5.36 & 2 \\ 13 & 45 \% & 41.82 / 5.31 & 3 \\ 12 & 40 \% & 41.90 / 5.23 & 3 \\ 11 & 4 \% & 319.63 / 8.44 & 1 \\ 10 & 29 \% & 41.37 / 5.3 & 1 \\ & & & \end{array}$


glyceraldehyde 3-phosphate dehydrogenase phosphoglycerate kinase

glyceraldehyde 3-phosphate dehydrogenase Os04g0338000

RGP2 protein

aspartate aminotransferase

L-iditol 2-dehydrogenase

OrysaZxa

L-iditol 2-dehydrogenase

elongation factor $\mathrm{Tu}$

aspartate-semialdehyde dehydrogenase

Os06g0215100

IAA-amino acid hydrolase

phosphoglycerate kinase

Os07g0120900

\section{Os04g0386600}

reversibly glycosylated polypeptide

succinyl-CoA synthetase $\beta$ subunit

glucose-6-phosphate 1-epimerase

Os03g0843300

hypothetical protein OsI_32784

Os03g0161100

glucose and ribitol dehydrogenase homolog

enoyl-[acyl-carrier protein] reductase I

malate dehydrogenase

malate dehydrogenase

Os05g0116000

Os02g0821001
EAY91751

NP_001053139

NP_001058317

NP_001053139

NP_001052494

CAA09470

NP_001048397

NP_001062412

Q75H81

NP_001062412

NP_001051912

NP_001051347

NP_001057134

NP_001043347

NP_001046020

NP_001058784

NP_001052622

CAA77235

NP_001047463

NP_001054126

NP_001051862

EAY77740

NP_001049041

Q75KH3

NP_001061557

NP_001064860

NP_001064860

NP_001054469

NP_001173211

$\begin{array}{ccccc}64 & 5 & 30 \% & 14.96 / 9.58 & 12 \\ 65 & 14 & 48 \% & 36.92 / 6.34 & 4 \\ 64 & 9 & 31 \% & 42.31 / 6.19 & 5 \\ 129 & 11 & 39 \% & 36.92 / 6.34 & 1 \\ 80 & 11 & 33 \% & 38.50 / 6.03 & 1 \\ 99 & 9 & 26 \% & 39.53 / 8.08 & 3 \\ 76 & 14 & 35 \% & 50.55 / 8.16 & 1 \\ 93 & 11 & 29 \% & 39.99 / 6.03 & 1 \\ 219 & 19 & 54 \% & 42.11 / 5.75 & 12 \\ 66 & 18 & 59 \% & 39.99 / 6.03 & 1 \\ 83 & 18 & 44 \% & 48.56 / 6.04 & 8 \\ 111 & 8 & 32 \% & 40.44 / 6.73 & 1 \\ 70 & 7 & 29 \% & 43.7 / 9.51 & 12 \\ 138 & 13 & 41 \% & 47.28 / 5.66 & 1 \\ 69 & 14 & 47 \% & 42.20 / 5.64 & 5 \\ 66 & 8 & 20 \% & 58.43 / 8 & 12 \\ 72 & 14 & 47 \% & 41.64 / 5.66 & 1 \\ 82 & 11 & 37 \% & 41.86 / 5.82 & 3 \\ 119 & 8 & 21 \% & 45.41 / 5.98 & 4 \\ 177 & 11 & 51 \% & 38.10 / 5.1 & 1 \\ 66 & 7 & 28 \% & 34.78 / 4.9 & 12 \\ 91 & 7 & 26 \% & 36.60 / 5.27 & 1 \\ 69 & 18 & 7 \% & 317.24 / 4.96 & 7 \\ 64 & 11 & 31 \% & 32.48 / 5.76 & 1 \\ 64 & 10 & 36 \% & 39.28 / 8.81 & 1 \\ 65 & 7 & 26 \% & 35.89 / 5.75 & 4 \\ 105 & 11 & 44 \% & 35.89 / 5.75 & 4 \\ 71 & 7 & 31 \% & 38.46 / 5.81 & 12 \\ 67 & 4 & 72 \% & 8.81 / 10.25 & 12\end{array}$


guanine nucleotide-binding protein subunit $\beta$-2-like 1 protein acyl-[acyl-carrier-protein] desaturase 2, chloroplastic malate dehydrogenase

Os03g0793700

guanine nucleotide-binding protein subunit $\beta$-2-like 1 protein hypothetical protein OsJ_12925

hypothetical protein OsJ_12925

globulin-like protein

Os03g0793700

hypothetical protein OsJ_12925

Os03g0327600

globulin-like protein

Os03g0327600

hypothetical protein OsJ_06082

Os01g0762500

Os03g0793700

Os11g0701100

translation initiation factor 3 subunit I

metal-dependent hydrolase-like protein

receptor protein kinase-like

hypothetical protein OsI_07904

Os03g0663800

Os03g0663800

Os03g0663800

unknown protein

Os03g0663800

Os03g0663800

lactoylglutathione lyase

Os03g0663800
NP_001043910

Q8S059

NP_001064860

NP_001051533

NP_001043910

EAZ28885

EAZ28885

AAM33459

NP_001051533

EAZ28885

NP_001049995

AAM33459

NP_001049995

EEE56662

NP_001044328

NP_001051533

NP_001068520

NP_001061508

BAD15421

BAD73679

EEC73520

NP_001173574

NP_001173574

NP_001173574

AAN05517

NP_001173574

NP_001173574

NP_001061172

NP_001173574

$\begin{array}{ccccc}77 & 6 & 27 \% & 36.67 / 5.97 & 7 \\ 66 & 14 & 39 \% & 45.08 / 6.39 & 1 \\ 65 & 8 & 33 \% & 35.89 / 5.75 & 4 \\ 67 & 13 & 31 \% & 52.44 / 6.78 & 2 \\ 65 & 6 & 31 \% & 36.67 / 5.97 & 7 \\ 110 & 9 & 23 \% & 49.98 / 7.74 & 2 \\ 76 & 7 & 21 \% & 49.98 / 7.74 & 2 \\ 64 & 9 & 18 \% & 52.38 / 6.78 & 2 \\ 64 & 15 & 35 \% & 52.44 / 6.78 & 2 \\ 66 & 10 & 26 \% & 49.98 / 7.74 & 2 \\ 64 & 10 & 39 \% & 39.25 / 6.3 & 12 \\ 66 & 7 & 23 \% & 52.38 / 6.78 & 2 \\ 72 & 10 & 39 \% & 39.25 / 6.3 & 12 \\ 66 & 8 & 15 \% & 53.83 / 9.14 & 6 \\ 66 & 7 & 24 \% & 56.78 / 9.09 & 6 \\ 88 & 9 & 28 \% & 52.47 / 6.78 & 2 \\ 76 & 9 & 29 \% & 31.86 / 6.12 & 1 \\ 121 & 8 & 26 \% & 36.53 / 5.94 & 8 \\ 71 & 8 & 30 \% & 29.60 / 6.19 & 1 \\ 86 & 7 & 16 \% & 70.30 / 7.1 & 5 \\ 69 & 10 & 16 \% & 81.34 / 9.36 & 12 \\ 96 & 10 & 35 \% & 45.51 / 6.07 & 2 \\ 66 & 10 & 35 \% & 45.51 / 6.07 & 2 \\ 161 & 9 & 30 \% & 45.51 / 6.07 & 2 \\ 107 & 7 & 41 \% & 35.44 / 5.57 & 12 \\ 67 & 10 & 35 \% & 45.51 / 6.07 & 2 \\ 72 & 10 & 35 \% & 45.51 / 6.07 & 2 \\ 64 & 9 & 39 \% & 32.88 / 5.51 & 1 \\ 103 & 8 & 31 \% & 45.51 / 6.07 & 2\end{array}$




$\begin{array}{ll}200 & \text { enoyl-[acyl-carrier protein] reductase I } \\ 201 & \text { unnamed protein product } \\ 202 & \text { hypothetical protein OsJ_13801 } \\ 203 & \text { putative glucanase } \\ 204 & \text { lactoylglutathione lyase } \\ 205 & \text { hypothetical protein } \\ 206 & \text { hypothetical protein OsI_11164 } \\ 207 & \text { hypothetical protein OsI_11164 } \\ 208 & \text { Q-soluble NSF attachment protein } \\ 209 & \text { Os06g0341300 } \\ 210 & \text { Os12g0626500 } \\ 211 & \text { Os03g0663800 } \\ 212 & \text { Os02g0580300 } \\ 213 & \text { 14-3-3-like protein gf14-6 } \\ 214 & \text { Os04g0462500 } \\ 215 & \text { Os08g0430500 } \\ 216 & \text { Os11g0546900 } \\ 217 & \text { Os08g0480800 } \\ 218 & \text { Os04g0404400 } \\ 219 & \text { hypothetical protein } \\ 220 & \text { OSJNBb0014D23.1 } \\ 221 & \text { Os03g0663800 } \\ 222 & \text { hydroxyacylglutathione hydrolase } \\ 223 & \text { inorganic pyrophosphatase } \\ 224 & \text { Os07g0170200 } \\ 225 & \text { Os05g0569500 } \\ 226 & \text { Cupin family protein, expressed } \\ 227 & \text { hypothetical protein OsJ_12925 } \\ 228 & \text { globulin-like protein } \\ & \\ & \\ & \end{array}$

$\begin{array}{lccccc}\text { NP_001061557 } & 73 & 9 & 34 \% & 39.28 / 8.81 & 1 \\ \text { BAH00330 } & 65 & 5 & 44 \% & 20.73 / 6.18 & 1 \\ \text { EAZ29742 } & 67 & 12 & 37 \% & 54.48 / 9.06 & 2 \\ \text { BAB85436 } & 181 & 12 & 42 \% & 34.23 / 5.35 & 4 \\ \text { NP_001061172 } & 83 & 12 & 46 \% & 32.88 / 5.51 & 1 \\ \text { AAT44171 } & 182 & 6 & 52 \% & 16.21 / 10.35 & 12 \\ \text { EEC75053 } & 134 & 5 & 33 \% & 31.78 / 5.11 & 1 \\ \text { EEC75053 } & 81 & 9 & 31 \% & 31.78 / 5.11 & 1 \\ \text { NP_001061446 } & 64 & 5 & 20 \% & 32.75 / 5.04 & 3 \\ \text { NP_001057565 } & 64 & 10 & 48 \% & 27.91 / 4.19 & 12 \\ \text { NP_001067326 } & 156 & 8 & 41 \% & 19.89 / 4.57 & 12 \\ \text { NP_001173574 } & 120 & 9 & 33 \% & 45.51 / 6.07 & 2 \\ \text { NP_001047234 } & 68 & 14 & 54 \% & 29.85 / 4.71 & 3 \\ \text { ABR25721 } & 87 & 5 & 58 \% & 16.42 / 4.57 & 3 \\ \text { NP_001053003 } & 64 & 8 & 37 \% & 29.96 / 4.76 & 3 \\ \text { NP_001061856 } & 118 & 5 & 30 \% & 28.98 / 4.78 & 3 \\ \text { NP_001068067 } & 109 & 13 & 56 \% & 29.36 / 4.83 & 3 \\ \text { NP_001062060 } & 68 & 13 & 48 \% & 29.10 / 4.85 & 3 \\ \text { NP_001052704 } & 219 & 12 & 48 \% & 31.33 / 4.9 & 12 \\ \text { BAD16983 } & 161 & 4 & 72 \% & 10.94 / 8.53 & 12 \\ \text { CAE05267 } & 154 & 6 & 12 \% & 74.92 / 5.76 & 12 \\ \text { NP_001173574 } & 75 & 9 & 33 \% & 45.51 / 6.07 & 2 \\ \text { NP_001050016 } & 71 & 9 & 46 \% & 29.00 / 5.43 & 1 \\ \text { NP_001054331 } & 150 & 10 & 50 \% & 24.29 / 5.59 & 1 \\ \text { NP_001058990 } & 75 & 6 & 21 \% & 31.09 / 9.6 & 7 \\ \text { NP_001056364 } & 124 & 10 & 35 \% & 26.74 / 5.58 & 12 \\ \text { ABF95817 } & 103 & 13 & 26 \% & 61.74 / 7.18 & 2 \\ \text { EAZ28885 } & 68 & 7 & 19 \% & 49.98 / 7.74 & 2 \\ \text { AAM33459 } & 120 & 9 & 21 \% & 52.38 / 6.78 & 2\end{array}$


hypothetical protein OsJ_25289

hypothetical protein OsJ_19146

Cupin family protein

hypothetical protein

thioredoxin peroxidase $\mathrm{A}$

hypothetical protein OsI_26825

protein of unknown function DUF1264 family protein

retrotransposon protein, putative, Ty3-gypsy subclass

Os03g0277500

thioredoxin 1

20S proteasome subunit $\beta 6$

Os03g0822200

Os11g0701100

Cupin family protein

Os03g0659300

Os05g0116100

Os05g0542500

unnamed protein product

unnamed protein product

unnamed protein product

Os09g0467200

triosephosphate isomerase (TIM)

20S proteasome subunit $\alpha 2$

unnamed protein product

hypothetical protein

triosephosphate isomerase (TIM)

triosephosphate isomerase (TIM)

unknown protein

triosephosphate isomerase (TIM)

$\begin{array}{lccccc}\text { EEE67666 } & 80 & 10 & 7 \% & 213.77 / 4.93 & 12 \\ \text { EEE64309 } & 65 & 7 & 21 \% & 30.55 / 6.66 & 1 \\ \text { ABF95817 } & 87 & 15 & 30 \% & 61.74 / 7.18 & 2 \\ \text { BAD81742 } & 99 & 5 & 46 \% & 18.85 / 9.00 & 12 \\ \text { P0C5C8 } & 89 & 6 & 31 \% & 24.23 / 5.97 & 1 \\ \text { EAZ04671 } & 67 & 5 & 40 \% & 23.72 / 5.78 & 2 \\ \text { NP_001044131 } & 66 & 13 & 60 \% & 27.72 / 5.98 & 3 \\ \text { ABB47110 } & 103 & 10 & 10 \% & 151.89 / 7.91 & 7 \\ \text { NP_001049720 } & 65 & 8 & 66 \% & 15.05 / 5.54 & 12 \\ \text { NP_001051587 } & 119 & 7 & 52 \% & 14.90 / 5.67 & 3 \\ \text { NP_001063603 } & 141 & 8 & 39 \% & 24.61 / 6.43 & 3 \\ \text { NP_001051733 } & 82 & 11 & 52 \% & 27.95 / 6.34 & 1 \\ \text { NP_001068520 } & 73 & 8 & 30 \% & 31.86 / 6.12 & 1 \\ \text { ABF95817 } & 70 & 10 & 21 \% & 61.74 / 7.18 & 2 \\ \text { NP_001050818 } & 94 & 5 & 50 \% & 15.17 / 5.48 & 1 \\ \text { NP_001054470 } & 67 & 7 & 46 \% & 23.73 / 5.81 & 3 \\ \text { NP_001056195 } & 66 & 10 & 36 \% & 20.50 / 5.89 & 3 \\ \text { AAA72362 } & 66 & 10 & 36 \% & 20.26 / 6.6 & 12 \\ \text { AAA72362 } & 65 & 10 & 35 \% & 20.26 / 6.6 & 12 \\ \text { AAA72362 } & 109 & 12 & 38 \% & 20.26 / 6.6 & 12 \\ \text { NP_001063423 } & 128 & 10 & 39 \% & 25.34 / 5.5 & 3 \\ \text { NP_001042016 } & 116 & 8 & 62 \% & 27.27 / 5.38 & 4 \\ \text { NP_001047516 } & 112 & 10 & 48 \% & 25.83 / 5.39 & 3 \\ \text { AAA72362 } & 75 & 9 & 28 \% & 20.26 / 6.6 & 12 \\ \text { BAD62040 } & 92 & 4 & 46 \% & 8.49 / 4.75 & 12 \\ \text { NP_001042016 } & 66 & 7 & 35 \% & 27.27 / 5.38 & 4 \\ \text { NP_001042016 } & 105 & 8 & 44 \% & 27.27 / 5.38 & 4 \\ \text { BAD53921 } & 67 & 11 & 17 \% & 70.92 / 8.08 & 12 \\ \text { NP_001063777 } & 118 & 13 & 43 \% & 32.715 / 6.96 & 4\end{array}$




$\begin{array}{ll}258 & \text { putative chaperonin 21 precursor } \\ 259 & \text { hypothetical protein } \\ 260 & \text { glutathione S-transferase } \\ 261 & \text { Os03g0197300 } \\ 262 & \text { Os03g0197300 } \\ 263 & \text { Os03g0197300 } \\ 264 & \text { Os03g0197300 } \\ 265 & \text { Os01g0210500 } \\ 266 & \text { hypothetical protein } \\ 267 & \text { Os03g0197300 } \\ 268 & \text { Os03g0197300 } \\ 269 & \text { hypothetical protein OsI_19379 } \\ 270 & \text { hypothetical protein OsI_28286 } \\ 271 & \text { Os05g0468800 } \\ 272 & \text { Os10g0437500 } \\ 273 & \text { Os08g0129200 } \\ 274 & \text { Os03g0305600 } \\ 275 & \text { Os07g0191700 } \\ 276 & \text { a-amylase inhibitor } \\ 277 & \text { hypothetical protein OsI_09038 } \\ 278 & \text { hypothetical protein OsI_01558 } \\ 279 & \text { hypothetical protein OsI_08519 } \\ 280 & \text { hypothetical protein OsJ_05706 } \\ 281 & \text { hypothetical protein OsI_11558 } \\ 282 & \text { hypothetical protein OsJ_33343 } \\ 283 & \text { regulator of ribonuclease activity } \\ 284 & \text { Os01g0184100 } \\ 285 & \text { Os01g0722800 } \\ 286 & \text { Os05g0157200 }\end{array}$

$\begin{array}{lccccc}\text { BAD35232 } & 64 & 13 & 69 \% & 23.20 / 5.72 & 3 \\ \text { BAD19892 } & 102 & 3 & 76 \% & 7.02 / 9.4 & 12 \\ \text { NP_001059595 } & 82 & 9 & 42 \% & 26.04 / 5.01 & 1 \\ \text { NP_001049271 } & 106 & 7 & 21 \% & 68.53 / 5.52 & 2 \\ \text { NP_001049271 } & 146 & 8 & 21 \% & 68.53 / 5.52 & 2 \\ \text { NP_001049271 } & 86 & 8 & 19 \% & 68.53 / 5.52 & 2 \\ \text { NP_001049271 } & 67 & 8 & 18 \% & 68.53 / 5.52 & 2 \\ \text { NP_001042368 } & 116 & 5 & 34 \% & 23.75 / 4.73 & 3 \\ \text { BAD87149 } & 111 & 4 & 47 \% & 12.71 / 11.12 & 12 \\ \text { NP_001049271 } & 175 & 6 & 18 \% & 68.53 / 5.52 & 2 \\ \text { NP_001049271 } & 67 & 6 & 18 \% & 68.53 / 5.52 & 2 \\ \text { EEC78937 } & 94 & 7 & 21 \% & 53.68 / 5.55 & 1 \\ \text { EAZ06044 } & 89 & 11 & 20 \% & 38.65 / 5.85 & 3 \\ \text { NP_001055802 } & 103 & 8 & 47 \% & 18.23 / 5.71 & 1 \\ \text { NP_001064677 } & 98 & 5 & 25 \% & 19.16 / 5.61 & 12 \\ \text { NP_001060914 } & 64 & 5 & 47 \% & 19.02 / 6.28 & 3 \\ \text { NP_001049884 } & 97 & 9 & 54 \% & 18.42 / 6.42 & 2 \\ \text { NP_001059096 } & 64 & 8 & 8 \% & 129.06 / 8.84 & 12 \\ \text { ACV41264 } & 65 & 5 & 35 \% & 15.89 / 6.51 & 2 \\ \text { EEC74046 } & 147 & 6 & 21 \% & 42.96 / 8.85 & 9 \\ \text { EEC70487 } & 124 & 5 & 36 \% & 17.91 / 6.41 & 12 \\ \text { EEC73809 } & 79 & 6 & 22 \% & 44.51 / 4.94 & 12 \\ \text { EEE56482 } & 80 & 11 & 15 \% & 90.63 / 8.69 & 12 \\ \text { EEC75250 } & 104 & 8 & 19 \% & 55.96 / 5.48 & 1 \\ \text { EEE51843 } & 92 & 8 & 19 \% & 61.38 / 6.98 & 5 \\ \text { ABR25651 } & 65 & 8 & 64 \% & 18.28 / 5.61 & 9 \\ \text { NP_001042231 } & 81 & 6 & 40 \% & 18.13 / 5.61 & 2 \\ \text { NP_001044103 } & 69 & 5 & 36 \% & 18.34 / 5.35 & 12 \\ \text { NP_001054704 } & 69 & 8 & 45 \% & 18.16 / 5.22 & 2\end{array}$




\begin{tabular}{|c|c|c|c|c|c|c|c|}
\hline 287 & hypothetical protein OsI_35528 & EAY80356 & 64 & 5 & $56 \%$ & $19.19 / 6.36$ & 12 \\
\hline 288 & Os01g0225600 & NP_001042461 & 88 & 6 & $52 \%$ & $16.29 / 5$ & 2 \\
\hline 289 & Os06g0363701 & NP_001174783 & 64 & 10 & $11 \%$ & $152.05 / 5.3$ & 12 \\
\hline 290 & hypothetical protein OsI_19752 & EEC79115 & 64 & 4 & $41 \%$ & $17.41 / 6.49$ & 1 \\
\hline 292 & retrotransposon protein & ABA95630 & 68 & 6 & $27 \%$ & $36.39 / 6.27$ & 9 \\
\hline 293 & hypothetical protein OsI_21855 & EEC80108 & 67 & 4 & $13 \%$ & $15.02 / 5.85$ & 1 \\
\hline 294 & hypothetical protein OsJ_09934 & EEE58599 & 66 & 4 & $58 \%$ & $11.23 / 10.32$ & 12 \\
\hline 296 & OSJNBa0009K15.7 & CAE05087 & 90 & 11 & $8 \%$ & $195.33 / 8.62$ & 11 \\
\hline 297 & hypothetical protein & AAL84309 & 64 & 7 & $22 \%$ & $35.02 / 6.51$ & 11 \\
\hline 298 & hypothetical protein & BAD05367 & 64 & 4 & $34 \%$ & $12.67 / 7.85$ & 12 \\
\hline 299 & Os06g0221300 & NP_001057177 & 65 & 6 & $32 \%$ & $18.45 / 6.18$ & 3 \\
\hline 300 & transposon protein & AAK52138 & 68 & 7 & $35 \%$ & $23.00 / 11.05$ & 9 \\
\hline 301 & putative gypsy-type retrotransposon & AAL58269 & 74 & 8 & $7 \%$ & $165.47 / 9.53$ & 7 \\
\hline
\end{tabular}

${ }_{b}^{a}$ Number of matched peptides.

bequence coverage.

${ }^{\mathrm{c}}$ Functional categories of the proteins. The numbers indicate the protein function category: 1 - Metabolism, 2 - Disease/defense, 3 - Cell structure, 4 - Energy, 5 - Signal transduction, 6 - Protein destination and storage, 7 - Cell growth/division, 8 - Protein synthesis, 9 -

Transcription, 10 - Transporters, 11 - Intracellular traffic and 12 - Unknown protein. 
Table S2 - The unknown proteins identified by MALDI-TOF-MS.

\begin{tabular}{|c|c|c|c|c|c|c|c|}
\hline $\begin{array}{l}\text { Protein } \\
\text { no. }\end{array}$ & Protein name & Accession no. & $\begin{array}{c}\text { MOWSE } \\
\text { score }\end{array}$ & $\mathrm{NMP}^{\mathrm{a}}$ & $\mathrm{SC}^{\mathrm{b}}$ & $\begin{array}{l}\text { Theoretical } \mathrm{Mr} \\
(\mathrm{kDa}) \text { and } \mathrm{pI}\end{array}$ & Function \\
\hline 15 & hypothetical protein & BAD61634 & 65 & 5 & $36 \%$ & $15.63 / 9.99$ & $12^{\mathrm{c}}$ \\
\hline 18 & hypothetical protein OsJ_11969 & EEE59627 & 65 & 4 & $26 \%$ & $13.99 / 4.99$ & 12 \\
\hline 19 & hypothetical protein & BAD20105 & 64 & 7 & $31 \%$ & $30.32 / 11.81$ & 12 \\
\hline 49 & Os02g0250600 & NP_001046445 & 64 & 9 & $22 \%$ & $47.34 / 6.4$ & 12 \\
\hline 109 & OSJNBa0052P16.16 & CAD39715 & 64 & 6 & $20 \%$ & $48.00 / 6.64$ & 12 \\
\hline 111 & Os05g0418000 & NP_001055566 & 64 & 9 & $28 \%$ & $50.07 / 5.44$ & 12 \\
\hline 118 & Os10g0188500 & NP_001176052 & 146 & 4 & $34 \%$ & $21.14 / 4.81$ & 12 \\
\hline 133 & Os02g0158900 & NP_001045960 & 70 & 10 & $31 \%$ & $44.69 / 5.47$ & 12 \\
\hline 134 & Os04g0429200 & NP_001173940 & 85 & 5 & $31 \%$ & $15.49 / 6.89$ & 12 \\
\hline 135 & hypothetical protein OsJ_11020 & EAZ27089 & 66 & 4 & $60 \%$ & $7.64 / 9.76$ & 12 \\
\hline 142 & hypothetical protein OsI_13391 & EAY91751 & 64 & 5 & $30 \%$ & $14.96 / 9.58$ & 12 \\
\hline 150 & OrysaZxa & Q75H81 & 219 & 19 & $54 \%$ & $42.11 / 5.75$ & 12 \\
\hline 154 & Os06g0215100 & NP_001057134 & 70 & 7 & $29 \%$ & $43.87 / 9.51$ & 12 \\
\hline 157 & Os07g0120900 & NP_001058784 & 66 & 8 & $20 \%$ & $58.43 / 8$ & 12 \\
\hline 162 & Os03g0843300 & NP_001051862 & 66 & 7 & $28 \%$ & $34.78 / 4.9$ & 12 \\
\hline 169 & Os05g0116000 & NP_001054469 & 71 & 7 & $31 \%$ & $38.46 / 5.81$ & 12 \\
\hline 170 & Os02g0821001 & NP_001173211 & 67 & 4 & $72 \%$ & $8.81 / 10.25$ & 12 \\
\hline 181 & Os03g0327600 & NP_001049995 & 64 & 10 & $39 \%$ & $39.25 / 6.3$ & 12 \\
\hline 183 & Os03g0327600 & NP_001049995 & 72 & 10 & $39 \%$ & $39.25 / 6.3$ & 12 \\
\hline 191 & hypothetical protein OsI_07904 & EEC73520 & 69 & 10 & $16 \%$ & $81.34 / 9.36$ & 12 \\
\hline 195 & unknown protein & AAN05517 & 107 & 7 & $41 \%$ & $35.44 / 5.57$ & 12 \\
\hline 205 & hypothetical protein & AAT44171 & 182 & 6 & $52 \%$ & $16.21 / 10.35$ & 12 \\
\hline 209 & Os06g0341300 & NP_001057565 & 64 & 10 & $48 \%$ & $27.91 / 4.19$ & 12 \\
\hline 210 & Os12g0626500 & NP_001067326 & 156 & 8 & $41 \%$ & $19.87 / 4.57$ & 12 \\
\hline
\end{tabular}




\begin{tabular}{|c|c|c|c|c|c|c|c|}
\hline 218 & Os04g0404400 & NP_001052704 & 219 & 12 & $48 \%$ & $31.33 / 4.9$ & 12 \\
\hline 219 & hypothetical protein & BAD16983 & 161 & 4 & $72 \%$ & $10.94 / 8.53$ & 12 \\
\hline 220 & OSJNBb0014D23.1 & CAE05267 & 154 & 6 & $12 \%$ & $74.92 / 5.76$ & 12 \\
\hline 229 & hypothetical protein OsJ_25289 & EEE67666 & 80 & 10 & $7 \%$ & $213.77 / 4.93$ & 12 \\
\hline 232 & hypothetical protein & BAD81742 & 99 & 5 & $46 \%$ & $18.85 / 9$ & 12 \\
\hline 247 & unknown protein & AAA72362 & 65 & 10 & $35 \%$ & $20.26 / 6.6$ & 12 \\
\hline 248 & unknown protein & AAA72362 & 109 & 12 & $38 \%$ & $20.26 / 6.6$ & 12 \\
\hline 252 & unknown protein & AAA72362 & 75 & 9 & $28 \%$ & $20.26 / 6.6$ & 12 \\
\hline 253 & hypothetical protein & BAD62040 & 92 & 4 & $46 \%$ & $8.49 / 4.75$ & 12 \\
\hline 272 & Os $10 \mathrm{~g} 0437500$ & NP_001064677 & 98 & 5 & $25 \%$ & $19.16 / 5.61$ & 12 \\
\hline 275 & Os07g0191700 & NP_001059096 & 64 & 8 & $8 \%$ & $129.06 / 8.84$ & 12 \\
\hline 278 & hypothetical protein OsI_01558 & EEC70487 & 124 & 5 & $36 \%$ & $17.91 / 6.41$ & 12 \\
\hline 279 & hypothetical protein OsI_08519 & EEC73809 & 79 & 6 & $22 \%$ & $44.51 / 4.94$ & 12 \\
\hline 280 & hypothetical protein OsJ_05706 & EEE56482 & 80 & 11 & $15 \%$ & $90.63 / 8.69$ & 12 \\
\hline 285 & Os01g0722800 & NP_001044103 & 69 & 5 & $36 \%$ & $18.34 / 5.35$ & 12 \\
\hline 287 & hypothetical protein OsI_35528 & EAY80356 & 64 & 5 & $56 \%$ & $19.19 / 6.36$ & 12 \\
\hline 289 & Os06g0363701 & NP_001174783 & 64 & 10 & $11 \%$ & $152.05 / 5.3$ & 12 \\
\hline
\end{tabular}

${ }_{\mathrm{b}}^{\mathrm{a}}$ Number of matched peptides.

${ }^{\mathrm{b}}$ Sequence coverage.

${ }^{\mathrm{c}} 12$ : Unknown proteins. 